\title{
IVF laboratory management in COVID-19 pandemic
}

\author{
Syed Waseem Andrabi ${ }^{*}$, Puneet Rana Arora ${ }^{2}$, Mir Jaffar ${ }^{3}$
}

\begin{abstract}
Background: Since the first report of severe acute respiratory syndrome coronavirus-2 (SARS-CoV-2), widely known as COVID-19, in late December 2019, it has spread worldwide. The eventual return of new normal has started to happen in most countries where the COVID-19 curve has flattened, and Assisted reproduction technology (ART) services are eventually resuming. Well-organized ART (embryology/andrology) laboratories safeguard the wellbeing of all staff, patients, and their gametes/embryos.

Main body: A well-organized pandemic management plan must be implemented in anticipation of possible subsequent COVID-19 waves. Apart from local and national guidelines, some mandatory changes need to be taken into considerations that will allow us to overcome the fear of this deadly pandemic, work smoothly and stop any possible transmission without comprising the quality control for successful treatment. These mandatory changes include conserving different supplies, reducing manpower needs, and various protective measures for non-clinical and clinical staff, patients, and gametes/embryos.
\end{abstract}

Conclusion: The current pandemic of COVID-19 suggests a well-organized action-oriented emergency plan to assure the wellbeing of all stakeholders.

Keywords: COVID-19, Infertility, Response plan, IVF Laboratory, embryology, and Andrology Laboratories, India

\section{Background}

Within the last two decades, severe acute respiratory syndrome (SARS) and the Middle East respiratory syndrome (MERS) emerged as highly pathogenic and were responsible for major respiratory disease outbreaks. The recent deadly human Coronavirus (SARS-CoV-2) in cells is mediated by using angiotensin-converting enzyme 2 (ACE2) receptors by binding with a 1273 amino acid, long spike (S) viral protein protruding a 'corona' like appearance [1]. ACE2 receptors have been reported in Leydig, Sertoli, theca, granulosa cells of the human ovary, and spermatogonia of the human testis [2]. Globally, the health care system has been under an unprecedented strain introduced by the COVID-19 pandemic, and to stop the spreading of SARS-CoV-2, all non-essential care treatments were discontinued in numerous countries. Although assisted reproductive technology (ART) also comes under the "nonessential" healthcare system, various international groups, and bodies such as the American Society for Reproductive Medicine (ASRM), European Society of Human Reproduction and Embryology (ESHRE), and British Fertility Society (BFS), raised the concern regarding discontinuing fertility treatments

*Correspondence: wasiandrabi@gmail.com

${ }^{1}$ Department of Embryology, Cloudnine Hospitals, Gurugram, Haryana, India. Full list of author information is available at the end of the article resulting in generating a difference of opinion to what to be considered as essential or non-essential. After the world health organization (WHO) announced COVID-19 as a pandemic, fertility treatments were suspended, as recommended by various fertility societies, including ASRM, ESHRE BFS, raising anxieties in patients with fertility issues [3]. Although, from June 2020 onwards, there has been some resumption in the ART treatment, however, there are still discrepancies regarding the manner and the extent of ART treatment to be offered. Although the COVID-19 pandemic has affected both public and private centers, all fertility societies have gradually recommended the resumption of ART treatment, highlighting the early identification of patients requiring immediate treatment [4].

\section{Positive Hope}

The viral presence in the reproductive tract in males affects fertility and highly increases the risks of sexually transmitted infections [5]. Up to date, the extent of existence and replication of viruses in the male reproductive system is not clear [6]; however, the Zika virus has been reported to stay up to one year in males after recovering from infection [7]. Salam and Horby [8] reported the transmission of 27 viruses in male semen [8]. Moreover, structural stability plays a vital role in this shedding 
process. Li D et al. [9] reported the transmission of COVID-19 into semen [9]; however, biases like low sample size, the stage of infection, and the time of the study (COVID-19 pandemic) altered the result. Furthermore, there was no crosscontamination of cryopreserved semen samples has been reported yet.

\section{Mandatory changes}

Per the centers for disease control and prevention (CDC) safety standards, it was mandatory for all front-line staff to use personal protective equipment (PPE), including face masks, disposable laboratory coats, eye protectors, and shoe covers. At least two alternate mini-teams should be made available to limit the spread of the virus if any staff is infected. In case of any staff being infected, at least two alternate mini-teams should be available to limit the spread of the virus. Proper safety measures should be followed, and all staff should be appropriately educated. Proper face masks and distance should be maintained and contact with patients should be avoided. Non-laboratory (clinicians and nurses) and non-medical (security, technicians) persons should be trained for liquid nitrogen tank filling under video conference call with embryologists for cryopreserved samples if lab staff is quarantined. Proper sanitization of equipment, devices, and workspace with detergents, UV irradiation, and disinfectants with proven efficiency should be performed after every procedure. In times of peak spread, the use of telehealth technologies in video conferencing and phone consultation should be given preference over the in-person faceto-face interactions. Honest counseling about the cycle cancellation in case of COVID-19 positive test before the stimulation, in-between stimulation, and before trigger should be done in advance. Apart from this, as the effect of COVID-19 infection on sperm, oocytes, embryos, implantation, and miscarriages is still unknown, it should also be discussed with the patient.
All the persons (both staff and patients) entering any fertility clinic should fill the ART Triage questionnaire to understand any potential source of infection [10]. Any potential infectious case should be referred to COVID-19 testing according to local and national guidelines. Some Basic recommendations as an early-level response plan in pre-pandemic management for ART laboratories are listed below in Table 1.

\section{Andrology Laboratory Recommendations}

As some studies have reported the possible viral transmission in either semen or testicular sample, proper necessary measures should be taken. Some possible recommendations needed to be made summarized in Table 2 .

Embryology Laboratory Recommendations For smooth working of embryology laboratories in COVID-19 pandemic, certain recommended precautions that need to be taken are summarized in Table 3 .

\section{Non-laboratory Recommendations}

All the possible transmission ways should be blocked starting from by proper 6-step hand-washing at entry before entering the laboratory, use of PPE kits by all staff, well-organized miniteams of staff, cutting down in-person interactions within laboratory staff and with patients, a proper social distancing between patients and staff, introduction of alarm sensors system in liquid nitrogen tanks, proper backup of all essential commodities, and removing outer packing of all media. Moreover, consumables should be adequately monitored and removed before taking inside the laboratory, avoiding unnecessary movement, extra mobile air filters, shearing of pens and papers should be discouraged, and door handle should be cleaned frequently.

Table 1: Early-level recommendations for ART laboratories to stop COVID-19 transmission.

\begin{tabular}{|l|l|}
\hline Recommendation & Basis of evidence \\
\hline $\begin{array}{l}\text { A spare cryogenic storage tank should be available to store } \\
\text { sufficient liquid nitrogen in case of possible Lockdown. }\end{array}$ & $\begin{array}{l}\text { Practice Committees of the American Society for } \\
\text { Reproductive Medicine, Society for Reproductive Biologists } \\
\text { and Technologists, and Society for Assisted Reproductive } \\
\text { Technology [11]. }\end{array}$ \\
\hline Maintaining records online. & $\begin{array}{l}\text { Practice Committee of Society for Assisted Reproductive } \\
\text { Technology; Practice Committee of American Society for } \\
\text { Reproductive Medicine [12]. }\end{array}$ \\
\hline Wearing proper masks and PPE kits to stop cross-contamination. & Recommendation based on expert opinion. \\
\hline Vaccinating all staff on a priority basis. & World Health Organization [13]. \\
\hline $\begin{array}{l}\text { Preparing emergency contact list for all clinical and non-clinical } \\
\text { staff. }\end{array}$ & $\begin{array}{l}\text { ESHRE Guideline Group on Good Practice in IVF Labs et } \\
\text { al., 2016 [14]. }\end{array}$ \\
\hline $\begin{array}{l}\text { Educating the possible disease transmission and mitigation } \\
\text { methods to all staff. }\end{array}$ & Kuhar et al., 2019 [15]. \\
\hline
\end{tabular}

\section{Summary and Conclusion}

COVID-19 pandemic has a severe risk for all healthcare workers and patients, including IVF laboratory workers. Any accidental exposure of contaminated fluids or materials poses a direct concern for IVF healthcare workers. Most of the standard operating procedures (SOP) are inadequate to face the aerosolmediated transmission of viruses. All SOPs should be revised following the national and local guidelines, with strict implementations to withstand future infections. Good collaboration between different units and team members is mandatory for smooth functioning when running IVF laboratories in times of crisis, such as the current COVID-19 pandemic. 
Table 2: Andrology laboratory recommendations during COVID-19

\begin{tabular}{|l|l|}
\hline Recommendation & Basis of evidence \\
\hline $\begin{array}{l}\text { As a precautionary measure, all males starting their fertility } \\
\text { treatments should be tested for COVID-19. }\end{array}$ & $\begin{array}{l}\text { Practice Committee of Society for Assisted Reproductive } \\
\text { Technology; Practice Committee of American Society for } \\
\text { Reproductive Medicine [12]. }\end{array}$ \\
\hline $\begin{array}{l}\text { Fertility preservation should be considered invulnerable males, } \\
\text { including males undergoing therapy and autoimmune and } \\
\text { inflammatory treatments. }\end{array}$ & Esteves et al [16]. \\
\hline $\begin{array}{l}\text { Where planned, a proper dedicated area of semen collection and } \\
\text { separate semen cryopreservation tank should be assigned. }\end{array}$ & Andrabi et al [17]. \\
\hline $\begin{array}{l}\text { A proper semen collection written instruction in local and national } \\
\text { language should always be available in the collection room before } \\
\text { sample collection to avoid in-person contact. }\end{array}$ & Andrabi et al [17]. \\
\hline $\begin{array}{l}\text { All andrology technicians/embryologists should strictly follow the } \\
\text { standard operating protocols in handling the semen samples. }\end{array}$ & Onigbinde et al [18]. \\
\hline $\begin{array}{l}\text { Proper filtration systems should be installed in the form of mobile } \\
\text { towers to increase air quality inside the andrology laboratory. }\end{array}$ & Recommendation based on expert opinion \\
\hline $\begin{array}{l}\text { All the materials used in performing andrological procedures } \\
\text { should be disposed of immediately after the procedure, followed } \\
\text { by thorough cleaning. }\end{array}$ & Recommendation based on expert opinion \\
\hline $\begin{array}{l}\text { In COVID-19 positive patients, home collection and proper care } \\
\text { can be an ideal way. }\end{array}$ & Recommendation based on expert opinion \\
\hline
\end{tabular}

Table 3: Embryology laboratory recommendations during COVID-19

\begin{tabular}{|c|c|}
\hline Recommendation & Basis of evidence \\
\hline $\begin{array}{l}\text { Avoiding in-person counseling and use of tele phone or email } \\
\text { calling. Adequate time should be given between procedures when } \\
\text { performing a thorough cleaning in ovum pickup areas. }\end{array}$ & Andrabi et al [17]. \\
\hline $\begin{array}{l}\text { Minimal embryology teams should be made available for worst- } \\
\text { case scenarios. }\end{array}$ & Andrabi et al [17]. \\
\hline $\begin{array}{l}\text { Extra care should be taken in follicular fluid handling during } \\
\text { screening procedures, especially in COVID-19 infection recovered } \\
\text { patients. }\end{array}$ & Recommendation based on expert opinion \\
\hline $\begin{array}{l}\text { After the proper follicular fluid screening, care should be taken in } \\
\text { the form of non-spillage of fluid, proper closing of the lid, and } \\
\text { immediate disposal should be taken care of. }\end{array}$ & Recommendation based on expert opinion \\
\hline $\begin{array}{l}\text { Pipette holders should be disinfected after every oocyte retrieval } \\
\text { procedure. }\end{array}$ & Recommendation based on expert opinion \\
\hline $\begin{array}{l}\text { Although no cross-contamination of gametes or embryos has been } \\
\text { reported yet; however, it is better to use a closed type vitrification } \\
\text { system that avoids direct contact of embryos with liquid nitrogen. }\end{array}$ & Porcu et al [19] \\
\hline $\begin{array}{l}\text { A separate liquid nitrogen tank should store cryopreserved } \\
\text { embryos and oocytes of patients having symptoms or tested } \\
\text { positive for COVID-19. }\end{array}$ & Recommendation based on expert opinion \\
\hline $\begin{array}{l}\text { After every procedure, proper disinfection of the workstation and } \\
\text { other equipment should be done with disinfectant, which is } \\
\text { alcohol-free, non-VOC releasing, non-fragranced, and effective } \\
\text { against bacteria, yeasts, viruses, and mycobactericidal. }\end{array}$ & Alaluf et al [20] \\
\hline $\begin{array}{l}\text { Although the chances of cross-contamination are very low in ART } \\
\text { laboratories due to antibiotics in media and continuous washing of } \\
\text { gametes repeatedly, every laboratory should properly follow its } \\
\text { standard operating protocols. }\end{array}$ & Onigbinde et al [18] \\
\hline $\begin{array}{l}\text { Some other suggestions during this COVID-19 pandemic period } \\
\text { include, following routine good laboratory practice, proper } \\
\text { protection of staff, proper cleaning of safety cabinets with tested } \\
\text { quaternary ammonium compounds lab disinfectants, proper pre } \\
\text { and post sanitization of all equipment, bed, trolley, and theatre } \\
\text { (General suggestions). }\end{array}$ & Recommendation based on expert opinion \\
\hline
\end{tabular}




\section{Abbreviation}

COVID-19: Coronavirus Disease 19; WHO: World Health Organization; ART: Assisted Reproductive Techniques; IVF: In-Vitro Fertilization; SARS-CoV-2: Severe Acute Respiratory Coronavirus 2; ASRM: American Society for Reproductive Medicine; ESHRE: European Society of Human Reproduction and Embryology; BFS: British Fertility Society; ACE2: Angiotensin-Converting Enzyme 2; CDC: Centers for Disease Control and Prevention; PPE: Personal Protective Equipment

\section{Declaration}

Acknowledgment

We express our gratitude to all scientific communities for their relentless work to produce the COVID-19 vaccine.

\section{Funding}

The authors received no financial support for their research, authorship, and/or publication of this article.

Availability of data and materials

Data will be available by emailing wasiandrabi@gmail.com.

\section{Authors' contributions}

Syed Waseem Andrabi (SWA) and Puneet Rana Arora (PRA) are the principal investigators of this manuscript (Viewpoint). SWA is the responsible author for the study concept, design, and writing. PRA is responsible for reviewing and editing the manuscript in its final form. Jaffar Mir (MJ) approved the final manuscript.

\section{Ethics approval and consent to participate}

We conducted the research following the Declaration of Helsinki. However, "Viewpoint Article" need no ethics committee approval.

\section{Consent for publication}

Not applicable

\section{Competing interest}

The authors declare that they have no competing interests.

\section{Open Access}

This article is distributed under the terms of the Creative Commons $\begin{array}{llll}\text { Attribution } & 4.0 & \text { International }\end{array}$ (http://creativecommons.org/licenses/by/4.0/), which permits unrestricted use, distribution, and reproduction in any medium, provided you give appropriate credit to the original author(s) and the source, provide a link to the Creative Commons license, and indicate if changes were made. The Creative Commons Public Domain Dedication waiver (http://creativecommons.org/publicdomain/zero/1.0/) applies to the data made available in this article, unless otherwise stated.

\section{Author details}

${ }^{1}$ Department of Embryology, Cloudnine Hospitals, Gurugram, Haryana, India. ${ }^{2}$ Centre for Infertility and Assisted Reproduction, Gurugram, Haryana, India. ${ }^{3}$ Valley Fertility center, Srinagar Kashmir, India

\section{Article Info}

Received: 05 August 2021

Accepted: 07 September 2021

Published: 19 September 2021

\section{References}

1. Hoffmann M, Kleine-Weber H, Schroeder S, et al. SARS-CoV-2 Cell Entry Depends on ACE2 and TMPRSS2 and Is Blocked by a Clinically Proven Protease Inhibitor. Cell. 2020;181(2):271280.e8. doi:10.1016/j.cell.2020.02.052
2. Zhou P, Yang XL, Wang XG, Hu B, Zhang L, Zhang W, Si HR, Zhu Y, Li B, Huang CL, Chen HD, Chen J, Luo Y, Guo H, Jiang RD, Liu MQ, Chen Y, Shen XR, Wang X, Zheng XS, Zhao K, Chen QJ, Deng F, Liu LL, Yan B, Zhan FX, Wang YY, Xiao GF, Shi ZL. A pneumonia outbreak associated with a new coronavirus of probable bat origin. Nature. 2020;579(7798):270-273. doi: 10.1038/s41586-020-2012-7.

3. Anifandis G, Messini CI, Daponte A, Messinis IE. COVID-19 and fertility: a virtual reality. Reprod Biomed Online. 2020;41(2):157159. doi:10.1016/j.rbmo.2020.05.001.

4. Alviggi C, Esteves SC, Orvieto R, Conforti A, La Marca A, Fischer R, Andersen CY, Bühler K, Sunkara SK, Polyzos NP, Strina I, Carbone L, Bento FC, Galliano D, Yarali H, Vuong LN, Grynberg M, Drakopoulos P, Xavier P, Llacer J, Neuspiller F, Horton M, Roque M, Papanikolaou E, Banker M, Dahan MH, Foong S, Tournaye H, Blockeel C, Vaiarelli A, Humaidan P, Ubaldi FM; POSEIDON (Patient-Oriented Strategies Encompassing IndividualizeD Oocyte Number) group. COVID-19 and assisted reproductive technology services: repercussions for patients and proposal for individualized clinical management. Reprod Biol Endocrinol. 2020;18(1):45. doi: 10.1186/s12958-02000605-z.

5. Liu W, Han R, Wu H, Han D. Viral threat to male fertility. Andrologia. 2018;50(11):e13140. doi: 10.1111/and.13140.

6. Mansuy JM, Suberbielle E, Chapuy-Regaud S, Mengelle C, Bujan L, Marchou B, Delobel P, Gonzalez-Dunia D, Malnou CE, Izopet J, Martin-Blondel G. Zika virus in semen and spermatozoa. Lancet Infect Dis. 2016;16(10):1106-1107. doi: 10.1016/S14733099(16)30336-X

7. Kurscheidt FA, Mesquita CSS, Damke GMZF, Damke E, de A Carvalho ARB, Suehiro TT, Teixeira JJV, da Silva VRS, Souza RP, Consolaro MEL. Persistence and clinical relevance of Zika virus in the male genital tract. Nature Review Urology 2019;16(4):211-230. https://doi.org/10.1038/s41585-019-0149-7.

8. Salam AP, and Horby PW. The Breadth of Viruses in Human Semen. Emer Inf Diseases. 2017;23(11):1922-1924. https://doi.org/10.3201/eid2311.171049.

9. Li D, Jin M, Bao P, Zhao W, Zhang S. Clinical Characteristics and Results of Semen Tests Among Men With Coronavirus Disease 2019. JAMA Network Open. 2020;3(5):e208292. doi:10.1001/jamanetworkopen.2020.8292.

10. ESHRE guidance on recommencing ART treatments. ESHRE COVID-19 Working Group. Published on the ESHRE website. 23/04/2020

11. Practice Committees of the American Society for Reproductive Medicine, Society for Reproductive Biologists and Technologists, and Society for Assisted Reproductive Technology. Electronic address: asrm@asrm.org. Cryostorage of reproductive tissues in the in vitro fertilization laboratory: a committee opinion. Fertility Sterility. 2020;114(3):486-491

doi 10.1016/j.fertnstert.2020.06.019

12. Practice Committee of Society for Assisted Reproductive Technology; Practice Committee of American Society for Reproductive Medicine. Guidelines for development of an emergency plan for in vitro fertilization programs. Fertility Sterility. 2008; 90(5):S131-33. doi 10.1016/j.fertnstert.2008.08.063.

13. World Health Organization. (2020). Guiding principles for immunization activities during the COVID-19 pandemic: interim guidance, 26 March 2020. World Health Organization. https://apps.who.int/iris/handle/10665/331590. License: CC BYNC-SA 3.0 IGO.

14. ESHRE Guideline Group on Good Practice in IVF Labs, De los Santos MJ, Apter S, Coticchio G, Debrock S, Lundin K, Plancha CE, Prados F, Rienzi L, Verheyen G, Woodward B, Vermeulen N. 
Revised guidelines for good practice in IVF laboratories (2015).

Human Reproduction. 2016;31(4):685-686. doi: 10.1093/humrep/dew016.

15. Kuhar DT, Carrico RM, Cox K, de Perio MA, Irwin KL, Lundstrom T, Overholt AD, Roberts KT, Russi M, Steed C (2019) Infection control in healthcare personnel: infrastructure and routine practices for occupational infection prevention and control services. Accessible version:

https://www.cdc.gov/infectioncontrol/guidelines/healthcarepersonnel/index.html.

16. Esteves SC, Lombardo F, Garrido N, Alvarez J, Zini A, Colpi GM, Kirkman-Brown J, Lewis SEM, Björndahl L, Majzoub A, Cho CL, Vendeira P, Hallak J, Amar E, Cocuzza M, Bento FC, Figueira RC, Sciorio R, Laursen RJ, Metwalley AM, Jindal SK, Parekattil S, Ramasamy R, Alviggi C, Humaidan P, Yovich JL, Agarwal A. SARS-CoV-2 pandemic and repercussions for male infertility patients: A proposal for the individualized provision of andrological services. Andrology. 2021;9(1):10-18. doi: 10.1111/andr.12809.
17. Andrabi SW, Jaffar M, Arora PR. COVID-19: New adaptation for IVF laboratory protocols. JBRA Assisted Reproduction. 2020;24(3):358-361. doi:10.5935/1518-0557.20200054.

18. Onigbinde OA, Ajagbe AO, Oyeniran OI, Chia T. Post-COVID19 pandemic: Standard operating procedures for gross anatomy laboratory in the new standard. Morphologie. 2020. ISSN 12860115. https://doi.org/10.1016/j.morpho.2020.10.004.

19. Porcu E, Tranquillo ML, Notarangelo L, Ciotti PM, Calza N, Zuffa S, Mori L, Nardi E, Dirodi M, Cipriani L, Labriola FS, Damiano G. High-security closed devices are efficient and safe to protect human oocytes from potential risk of viral contamination during vitrification and storage especially in the COVID-19 pandemic. J Assist Reprod Genet. 2021; 38(3):681-688. doi: 10.1007/s10815-021-02062-y.

20. Alaluf MG, Pasqualini A, Fiszbajn G, Botti G, Estofan G, Ruhlmann C, Solari L, Bisioli C, Pene A, Branzini C, Quintero Retamar A, Checkherdemian V, Pesce R, Serpa I, Lorenzo F, Avendaño C, Alvarez Sedo C, Lancuba S. COVID-19 risk assessment and safety management operational guidelines for IVF center reopening. J Assist Reprod Genet. 2020 Nov; 37(11):26692686. doi: 10.1007/s10815-020-01958-5. 